\title{
Influence of Input Value and Labor Expenditure on Output Value: A Case of Micro and Small Scale Industry in Indonesia
}

\author{
Tongam Sihol Nababan ${ }^{a}$, Elvis Fresly Purba ${ }^{b}$, Jongkers Tampubolon $^{c}$ \\ ${ }_{a, b, c}$ Nommensen HKBP University, Medan, Indonesia \\ tsnababan@gmail.com
}

\begin{abstract}
Objectives of the study are: (1) to estimate the influence of input value and labor expenditure on the output of micro and small industries in Indonesia, (2) to analyze the form of translog production function that is compatible with micro and small industries in Indonesia. The analytical method used is descriptive method and analysis of translog production functions with scenarios: linear translog function, complete second-order or quadratic linear translog function, and linear translog function with interaction. Results showed that (1) the function of linear translog production with interaction was more suitable used to estimate the production output of micro and small industries in Indonesia, (2) input value and labor expenditure had a positive and significant effect on output values, (3) micro-industry enterprises more emphasis on the allocation of larger workforce, while small-scale industry emphasizes greater allocation of input value, (4) the allocation of input value and labor expenditure are more efficient in micro-industries compared to small-scale industries.
\end{abstract}

Article Info

- Received : October 19, 2019

- Revised : January 11, 2020

- Published : January 16, 2020

- No. Pages : 45-60

- DOI : 10.33019/ijbe.v4i1.246

- JEL : M11, M54, O14

- Keywords : input value, output value, labor expenditure, translog production function, micro-industry, small-scale industry

\section{Introduction}

Indonesia's economy will have a strong fundamental if micro and small-scale industries (MSI) have become the main actors of productive and competitive in the national economy (Hamzah et al., 2018). To that end, the economic development of the people through empowerment MSI should be a priority of national development in the long term. The main challenge facing the future is to accelerate efforts to strengthen Indonesia's economic structure with a core of MSI as a major driver of economic growth, to reduce poverty and increase employment. Fatusin (2014) states that small-scale industries have attracted indigenous labor, account for a substantial part of the total manufacturing value-added, employ significant number of people and offer strong grounds for linkage creation between rural and urban population. Jasra et al. (2011) also express that MSIs are being considered as engines of economic growth worldwide. One of the most important roles of MSIs includes poverty alleviation through job creation. Further, the establishment and promotion of the small-scale enterprises are considered to be the solution to many of the problems of the developing economies (Batool \& Zulfiqar, 2013; Dalton et al., 2018). 
According to Widiastudi et.al (2011), small industry has the characteristics of a micro-scale, scattered across Indonesia, labor-intensive, relatively small investments and generate high added value. Another characteristic is to have a low entry barrier (using simple technology to associate, and does not require high skill), the source of creation of new entrepreneurs (Hamali, 2015), have a high degree of flexibility in anticipation of the changing dynamics of the market and are resistant to the economic crisis turmoil (Farradinna et al., 2018).

Survey of Small and Micro Industries Year 2018 by BPS (Indonesian Statistic Board) states that Indonesia's natural economic development of MSI is always portrayed as a sector with an important role for the historical experience shows MSI able to withstand the economic crisis ever experienced by Indonesia several years earlier. Moreover, because the majority of Indonesia's population is less educated then tried on a sector MSI is the right choice, where education is not an absolute requirement in the business sector MSI and live in the activities of small micro either of the traditional and modern, and can absorb a lot of labor.

The business of MSI is one of the economic activities that thrive in Indonesia. Based on the survey in 2017 by BPS, there were 4.46 million MSI businesses spread across Indonesia, 4.10 million $(91.96 \%)$ of them were micro industries and the rest were small-scale industries. Minimal capital, flexibility in running the business, products/services produced close to the needs of the community, as well as the use of local resources become characteristic of supporting the development of this business, MSI employment is still concentrated in Java, where about 6.88 million (63.82 percent) were on this island. Areas with the highest proportions of employment are the provinces of East Java by 2.72 million ( 25.20 percent), Central Java Province amounted to 1.94 million (17.98 percent), and the West Java province of 1.45 million (13, 50 percent). Meanwhile, the region with the lowest proportion of employment were the provinces of North Borneo for 12,67 thousand ( 0.12 percent), West Papua Province amounted to 20.52 thousand ( 0.19 percent), and Papua Province amounted to 25.32 thousand ( 0.23 percent).

BPS (2018) also reported that business expenses of MSI include expenses of raw materials and auxiliary materials, the use of lubricants and fuels, electricity consumption, water consumption valuable economic, transport, shipping, and postal mail, telephone, internet, and other communications, stationery, the cost of interest on loans, lease land or buildings for businesses, rental vehicles, machinery, tools, equipment, and other capital goods, maintenance and minor repairs of capital goods including replacement parts, indirect taxes, packing, packing material and packing, industrial services done other party, the other party services in order, and other expenses (except expenses for remuneration of workers). Total expenditure of MSI business amounted to 327.77 trillion rupiahs. Operating revenues of MSI include revenue from production, industrial services, and income from other activities are still in touch with their business. Total income of the MSI in 2017 amounted to 602.46 trillion rupiahs. The proportion of operating revenue based on archipelago dominated by Java Island was 68.72 percent of the total national income.

In general, small-scale and micro industrial profile in 2017 has described the process of business operations that include their inputs, labor, and output. In the profile, the input is costs incurred in the production process except for expenditures for the remuneration of workers. The number of workers is the number of employees work daily. While the output is the value of the output produced from the process of industrial activity expressed in terms of revenue. Therefore, these three elements (inputs, labor, and output) need to be estimated and analyzed to determine the influence of the relationship between the inputs, labor and output in a 
production process. Estimation and analysis will be performed on micro and small-scale industries in Indonesia.

One model that can be used to estimate the effect of labor between the input and output is a production function (Yasar et al., 2008). The production function shows the nature of the relationship between the factors of production and production level is achieved. Besides the production, function can also be described mathematically in various combinations of input used to generate a specific output. In the economic analysis, there are some types of production functions are used, such as the Cobb-Douglass production function (Woo \& Lee, 2011; Pradan $\&$ Mukherjee, 2018), the production function CES (Constant Elasticity of Substitution), the production function VES (Variable Elasticity of Substitution), and the translog production function (transcendental logarithm) (Shanmugam \& Kulshreshtha, 2002).

The characteristics of the input factors and micro industries in Indonesia are dynamic in which technology is used to change and may also be followed by changes in inputs, the production function that is performed in this study is the translog production function. According to Damanik and Effendi (2009), the assumption that the elasticity of production is not constant, and technological change is neutral then the relevant production function meets these requirements is the production function translog (transcendental logarithm). However, Pavelescu (2011) suggested that the translog production function can be used in a variety of alternatives, such as translog function linear, non-linear translog functions, quadratic translog function complete and incomplete quadratic translog function.

Based on the above-mentioned phenomenon, research questions to be answered are: (1) How does the value of the input and labor expenditures to micro and small industrial output in Indonesia? (2) Which of translog production function according to the micro and small industry in Indonesia? (3) What is the level of efficiency of use of inputs and the value of labor expenditure micro and small industry in Indonesia?

\section{Literature Review}

\section{Production Factors and Translog Production Function}

Factors of production are the objects that are provided by natural or created by humans, which can be used to produce goods and services. Factors of production are also called inputs. According to Soekartawi (2003) factors of production are often referred to as "victims" production because the production factor "sacrificed" to produce the production. To produce a product, the necessary knowledge of the relationship between the factors of production (input) and producing results (output) is essential (Evans et al., 2000; Hudcovský et al., 2017). In this study, the analyzed types of production factors are input values and labor. Meaning or definition of both factors of production uses the definition given by the BPS (2017). Input value is an intermediate cost incurred in the production process. Total manpower is the number of employees with paid workers and unpaid workers. Output value is the value of output produced from industrial activities.

In this study, translog production function used to estimate the relationship between the factors of production and production level. According to Yudhawisastra (2011), translog production function constitutes common form of production function Cobb-Douglas. But the difference is that the translog function includes the polynomial with degree two (Agung et al., 2008). In general, the translog production function formulated as follows (Agung et al., 2008):

For bivariate input $\left(X_{1}, X_{2}\right)$ translog function can be expressed as follows: 
$\ln Q=\beta_{o}+\beta_{1} \ln X_{1}+\beta_{2} \ln X_{2}+\beta_{3}\left(\ln X_{1}\right)^{2}+\beta_{4}\left(\ln X_{2}\right)^{2}+\beta_{5}\left(\ln X_{1}\right)\left(\ln X_{2}\right)$

$\beta_{\mathrm{o}}$ can be a function of the technology index $\mathrm{A}$, in its simplest form $\beta_{\mathrm{o}}=\ln A$ like in the function of Cobb Douglas, or quadric function of $\ln A$, i.e. $\beta_{0}=\ln \propto_{o}+\alpha_{1} \ln A+\alpha_{2}(\ln A)^{2}$. Function or model above in accordance with the linear model univariate or multiple regression (multiple regression) with linear parameters in $\beta \mathrm{j}, \mathrm{j}=0,1, \ldots, 5$. In the right-hand side there is a linear form in $\ln X_{1}$ dan $\ln X_{2}$, i.e.:

$\beta_{o}+\beta_{1} \ln X_{1}+\beta_{2} \ln X_{2}$

and form of degree two as below:

$\beta_{3}\left(\ln X_{1}\right)^{2}+\beta_{4}\left(\ln X_{2}\right)^{2}+\beta_{5}\left(\ln X_{1}\right)\left(\ln X_{2}\right)$

This polynomial with degree two is what distinguishes the translog function with input bivariate of Cobb Douglas function. Thus, $\beta_{3}=\beta_{4}=\beta_{5}=0$ will be obtained the Cobb Douglas function. Translog function above can also be stated in the form below.

$Q=A X_{1}{ }^{u} X_{2}^{v}$

with

$A=\exp \left(\beta_{o}\right)$

$u=\beta_{1}+\beta_{3} \ln X_{1}+\beta_{5} \ln X_{2}$

$v=\beta_{2}+\beta_{4} \ln X_{2}$

or

$Q=A X_{1}{ }^{u 1} X_{2}^{12}$

with

$A=\exp \left(\beta_{o}\right)$

$u_{1}=\beta_{1}+\beta_{3} \ln X_{1}+(1 / 2) \beta_{5} \ln X_{2}$

$u_{2}=\beta_{2}+\beta_{4} \ln X_{2}+(1 / 2) \beta_{5} \ln X_{1}$

The equation of $\mathrm{Q}$ has a form like a Cobb Douglas function. The difference lies in the usage of aggregate inputs $u_{1}$ and $u_{2}$, which is the linear function of $\ln X_{1}$ and $\ln X_{2}$ as a replacement parameter $\alpha$ and $\beta$ as in the Cobb Douglas function.

\section{Output Elasticity, Technical Substitution, and Substitution Elasticity}

Output Elasticity (OE) of $X_{1}$ dan $X_{2}$ for translog function as equation (1) can be stated as follows.

$$
\begin{aligned}
& \delta \ln Q / \delta \ln X_{1}=O E_{1}=\beta_{1}+2 \beta_{3}\left(\ln X_{1}\right)+\beta_{5}\left(\ln X_{2}\right) \\
& \delta \ln Q / \delta \ln X_{2}=O E_{1}=\beta_{2}+2 \beta_{4}\left(\ln X_{1}\right)+\beta_{5}\left(\ln X_{1}\right)
\end{aligned}
$$

This function clearly shows that both $\mathrm{OE}_{1}$ and $\mathrm{OE}_{2}$ is a linear function of the bivariate input $\operatorname{logarithm}\left(\ln X_{1}, \ln X_{2}\right)$. As is well known, the elasticity of output $X_{1}$ is a proportional rate of change of the output $\mathrm{Q}$ to $X_{1}$, which in this case depends on $X_{2}$, so it is not a constant value.

Coefficient of tangent to the isoquant at a point is $X_{1}$ that should be substituted for $X_{2}\left(X_{2}\right.$ for $X_{1}$ ) to maintain the output concerned. So, the rate of technical substitution or RTS is defined as the opposite of the coefficient of tangent that the relation is obtained as follows:

$R T S=-d X_{2} / d X_{1}$

Total differentiation from the translog function above is:

$d \ln Q=\left[\delta \ln Q / \delta \ln X_{1}\right] \cdot d \ln X_{1}+\left[\delta \ln Q / \delta \ln X_{2}\right] \cdot d \ln X_{2}$ 
Thus, obtained :

$d Q / Q=\left[\delta Q / \delta X_{1}\right] \cdot\left[X^{1} / Q\right] \cdot\left[d X_{1} / X_{1}\right]+\left[\delta Q / \delta X_{2}\right] \cdot\left[X_{2} / Q\right] \cdot\left[d X_{2} / X_{2}\right]$

and

$d Q=\left[\delta Q / \delta X_{1}\right] \cdot\left[d X^{1}\right]+\left[\delta Q / \delta X_{2}\right] \cdot\left[d X_{2}\right]$.

Due to move along isoquant $d Q$ must be equal to zero, then we obtain:

and

$R T S=-d X_{2} / d X_{1}=Q_{1} / Q_{2}$

where $\mathrm{Q}_{\mathrm{i}}=\delta Q / \delta X$. So, translog function as equation (1) has been shown or proven that the RTS at a point is equal to the quotient between marginal production for $X_{1}$ with marginal production for $\mathrm{X}_{2}$. Then, it will be obtained:

$R T S=-\frac{\beta^{1}+2 \beta_{2} \ln X_{1}+\beta_{5} X_{2}}{\beta_{2}+\beta_{4} \ln X_{2}+\beta_{5} X_{2}}\left(X_{2} / X_{1}\right)$

Based on the number of RTS can be obtained:

$\ln \left[\left(\delta Q / \delta X_{1}\right) /\left(\delta Q / \delta X_{2}\right)\right]=\ln \left[V\left(X_{1}, X_{2}\right)\right]-\ln \left[W\left(X_{1}, X_{2}\right]+\ln \left(X_{2} / X_{1}\right)\right.$

with

$V\left(X_{1}, X_{2}\right)=\beta_{1}+2 \beta_{3} \ln X_{1}+\beta_{5} \ln X_{2}$

$W\left(X_{1}, X_{2}\right)=\beta_{1}+2 \beta_{4} \ln X_{2}+\beta_{5} \ln X_{1}$

With regard $\ln \left[\left(\delta Q / \delta X_{1}\right) /\left(\delta Q / \delta X_{2}\right)\right]$ as the function of $\ln \left(X_{2} / X_{1}\right)$, the derivate is obtained as follows:

$\frac{1}{\sigma}=\frac{d\left\{\ln \left[\left(\delta Q / \delta X_{1}\right) /\left(\delta Q / \delta X_{2}\right)\right]\right\}}{d\left\{\ln \left(X_{2} / X_{1}\right)\right\}}$

which $\sigma$ is a substitution elasticity between $X_{1}$ and $X_{2}$ based on the function of $Q\left(X_{1}, X_{2}\right)$, however, it raises a problem to derivate the function of $\ln \left[V\left(X_{1}, X_{2}\right)\right]$ and $\ln \left[W\left(X_{1}, X_{2}\right)\right]$ to $\ln \left(X_{2} / X_{1}\right)$, because both of these functions are generally difficult to express as a function of the input element for $X_{1} / X_{2}$. In this regard, it is in this section shall be considered a special circumstance, namely with the constraints:

$2 \beta_{3}=2 \beta_{4}=-\beta_{5}$

so that the functions $V$ and $W$ can be expressed as a function of the input ratio $X_{1} / X_{2}$, as follows:

$V\left(X_{1}, X_{2}\right)=\beta_{1}+\beta_{5} \ln \left(X_{2} / X_{1}\right)$

$W\left(X_{1}, X_{2}\right)=\beta_{2}-\beta_{5} \ln \left(X_{2} / X_{1}\right)$

Furthermore, there will be obtained:

$d\left\{\ln V\left(X_{1}, X_{2}\right)\right\} / d\left\{\ln V\left(X_{2}, X_{1}\right)\right\}=\beta_{5} /\left[\beta_{1}+\beta_{5} \ln \left(X_{2} / X_{1}\right)\right]$

$d\left\{\ln W\left(X_{1}, X_{2}\right)\right\} / d\left\{\ln V\left(X_{2}, X_{1}\right)\right\}=-\beta_{5} /\left[\beta_{1}-\beta_{5} \ln \left(X_{2} / X_{1}\right)\right]$

Finally obtained:

$1 / \sigma=1+\beta_{5} /\left[\beta_{1}+\beta_{5} \ln \left(X_{2} / X_{1}\right)\right]-\beta_{5} /\left[\beta_{2}-\beta_{5} \ln \left(X_{2} / X_{1}\right)\right]$

So the substitution elasticity:

$$
\begin{aligned}
& \left.\sigma=\left[\beta_{1}+\beta_{5} \ln (k)\right]\left[\beta_{2}-\beta_{5} \ln (k)\right]-\beta_{5}=\left[\beta_{1}+\beta_{5} \ln (k)\right]+\beta_{5}=\beta_{2}-\beta_{5} \ln (k)\right] \\
& \text { or } \\
& \sigma=-\beta_{5}\left(\beta_{1}-\beta_{2}\right)[1+\ln (k)]-\left[\beta_{5} \ln (k)\right]^{2}
\end{aligned}
$$


where is $k=X_{2} / X_{1}$.

There are several reasons to use a translog production function, namely:

1) The assumption that the elasticity of production is not constant, and technological change is neutral then the relevant production function meets these requirements is the translog production function (Damanik \& Effendi, 2009).

2) Reasons to use transcendental function logarithm (translog) is because this function provides several advantages, namely (Pavelescu, 2011):

a. Unlike Cobb Douglas, translog function does not make such an assumption perfect substitution between factors of production or perfect competition in the market of production factors.

b. The concept of the production function translog allows for a linear relationship between output and production factors are calculated to move to a relationship that is not linear.

3) Faber (2015) as cited by Paridan (2016) states that another advantage of the translog production function is basic economic theory is a powerful, flexible function form, and is less sensitive to extreme observations. Translog function also provides substantially richer specification of the relationship between growth and production input factors than to approach Douglas Cobb or more linear approach. In particular, this allows the testing of the interaction between factors input into a determined framework.

\section{Previous Studies}

According to Gaspersz (2011), many studies choose to use a translog form because in essence does not impose limitations or restrictions. But in its estimation, it is frequent inadequate statistically, because of the very limited data and observation period research. Estimates translog function would be better to have more degrees of freedom. Several studies have used the estimated translog production function such as Lyu et al. (1984), Kim (1992), Stern (1994), Ray (1999), Khalil (2005), Baum \& Linz (2009), Krishnapillai \& Thompson (2012), Muwanga (2017), Lin \& Atsagli (2017) and Kim (2019).

Lyu et al. (1984) found that to estimate the productivity of agricultural products translog production function approach is better than the Cobb-Douglas. Kim (1992) has examined existing methods of estimating the translog production function and provides a general framework that allows for variable returns to scale. The model is based on the inverse input demand function and embeds a nonhomothetic production technology. The examination has indicated that estimation methods are valid only for homogeneous technologies with fixed scale effects. Stern (1994) has tried the accuracy of the translog approximation. Various simulation studies have generated different assessments. It is shown that when data are generated using known elasticities but no explicit production or cost function, the translog estimates of own price and cross-price elasticities prove reasonably accurate. Ray (1999) has used an estimated translog production function to obtain output- and input-oriented measures of scale efficiency at an observed input bundle. The model shows that the estimated model can be used to determine the optimal quantity of labor input for an exogenously fixed quantity of capital.

Khalil (2005) have used the translog production function to estimate the elasticity of production for manufacturing industries in Jordan. Results show that the capital-labor substitution ability larger than the capital substitution ability materials and labor-material. Baum \& Linz (2009) have used the model of translog production function to estimate the relationship of total cost with equation includes the log levels of some factors, the level of output, their squares, and their cross-products. They have found that given differentiability of the cost function, the cost shares of all inputs can be expressed as elasticities of the cost function concerning the input 
prices. Krishnapillai \& Thompson (2012) also have used a translog production function to estimate the elasticity of substitution in the manufacturing industry in the United States. The results showed that the capital, electricity, labor and mutually substituted. Electrical energy has a low cross elasticity of capital and capital, but capital and labor strong substitutes on electrical energy. However, the use of translog production function should use more observational data.

By using the translog production function Muwanga (2017) found that the male labor force is more productive than the female labor force, the productivity of women to grow more slowly than productivity of man, so it is easier to substitute labor against capital men compared with women workers. Lin \& Atsagli (2017) have applied the translog production function to investigate technical change and energy substitution possibilities among petroleum, coal and electricity over the period 1980-2012 in South Africa. The study concludes all energy inputs are found to be substitutes. In his study to analyze the effects of the carbon tax on power generation in substitution and complement scenarios, Kim (2019) has used the translog function for modelling of power generation. Moreover, the result suggests that the translog function model is available for analysis of electricity industry under environmental policies.

\section{Data and Specifications Model}

\section{Data}

The data used in this research is secondary data comprises a cross-section of the data input value, the amount of labor, and the value of output in each of the provinces in Indonesia. Data sourced from the BPS were limited to the data from 2015 until 2017.

\section{Specifications Model}

In this study, the estimated translog function performed in bivariate input value is input and labor expenditures. Thus translog function can be expressed as follows:

$\ln Q=\beta_{o}+\beta_{1} \ln I N+\beta_{2} \ln T K_{2}+\beta_{3}\left(\ln I N_{1}\right)^{2}+\beta_{4}(\ln T K)^{2}+\beta_{5}(\ln I N)(\ln T K)+e$

Where $\mathrm{Q}$ is the value of output, IN is the value of the input, and TK is the amount of the labor.

To get the estimate translog function better, it follows the model of Agung et al. (2008), then this function will be estimated in the five scenarios:

Model 1: Linear Translog Function

$\operatorname{Ln} Q=\beta_{o}+\beta_{1} \operatorname{LnIN}+\beta_{2} \operatorname{LnTK}+e$

Model 2: Linear Translog Function Second Order (Complete Quadric)

$\operatorname{Ln} Q=\beta_{o}+\beta^{1} \operatorname{LnIN}+\beta_{2} \operatorname{LnTK}_{2}+1 / 2 \beta_{3}(\operatorname{lnIN})_{1}^{2}+\beta_{5}(\operatorname{LnIN})(\ln T K)+1 / 2 \beta_{22}(\operatorname{LnTK})^{2}+e$

Model 3: Quadratic Translog Function after the Excluded Variable based on Model 2.

Model 4: Linear Translog Function with interaction.

$\operatorname{Ln} Q=\beta_{o}+\beta_{1} \operatorname{LnIN}+\beta_{2} \operatorname{LnTK}_{2}+\beta_{5}(\operatorname{LnIN})(\operatorname{LnTK})+e$

The translog production function to be estimated for the industry group Micro and Small Industries. In addition to the estimated translog production function, this study also estimated the level of industrial production efficiency between the micro and small industries.

Model 5: Analysis of Production Efficiency Level

The level of industrial production efficiency for micro and small industries is estimated using the Cobb-Douglas production model, with formulation: 
$Q_{i t}=\alpha T K_{i t}^{\beta}$

\section{Results}

\section{Estimation of Translog Production Function of Micro-Industry}

Table 1 presents the results of the production function translog estimates for 2015, 2016 and 2017. For 2015 and 2017, Table 1 shows that the estimated Model 1 (translog function linear) is under the theory that LnIN variable (input value) and LnTK (expenditure of labor) is positive. In Model 1 is estimated elasticity of output is constant. In Model 2 (second-order linear translog function or complete quadratic) variable, $\operatorname{LnIN} *$ LnTK expressed as a variable out (excluded), so it is not included in the estimate, and the result is Model 3. However, estimation Model, 3 is less consistent with the theory, where the coefficients LnTK is negative. While estimates of Model 4 (translog function linear interaction) is consistent with the theory. Thus the estimation of translog production function that is most appropriate to be analyzed is the Model 4, where the elasticity of his output is not constant. Estimation Model 4 shows that for the year 2015 and 2017, the value of the input positive and significant impact on the value of output. While labor expenditure has positive influence on the value of output but not significant. Then change the interaction of input values and labor expenditures can raise the value of output but not significantly.

Table 1. Estimation of Translog Production Function of Micro Industry Year 2015-2017

\begin{tabular}{|c|c|c|c|c|}
\hline \multirow{3}{*}{ Variable } & \multicolumn{4}{|c|}{ Year 2015} \\
\hline & Model 1 & Model 2 & Model 3 & Model 4 \\
\hline & Coefficient & Coefficient & Coefficient & Coefficient \\
\hline LnIN & $0.818^{\mathrm{a}}$ & $1.809^{\mathrm{a}}$ & $1.809^{\mathrm{a}}$ & $0.826^{\mathrm{a}}$ \\
\hline LnTK & $0.139^{\mathrm{a}}$ & $-1.136^{c}$ & $-1.136^{c}$ & 0.145 \\
\hline LnIN*LnIN & & $-0.073^{c}$ & $-0.073^{c}$ & \\
\hline LnIN*LnTK & & Excluded & & 0.001 \\
\hline LnTK*LnTK & & $0.103^{b}$ & $0.103^{b}$ & \\
\hline Constant & $1.396^{\mathrm{a}}$ & 2.475 & 2.475 & 1.298 \\
\hline F stat & $2543.75^{a}$ & $1371.09^{a}$ & $1373.3^{\mathrm{a}}$ & $1639.47^{a}$ \\
\hline $\mathrm{R}^{2}$ & 0.994 & 0.995 & 0.995 & 0.994 \\
\hline $\operatorname{Adj} R^{2}$ & 0.994 & 0.994 & 0.994 & 0.994 \\
\hline
\end{tabular}

\begin{tabular}{|c|c|c|c|c|}
\hline \multirow{3}{*}{ Variable } & \multicolumn{4}{|c|}{ Year 2016} \\
\hline & Model 1 & Model 2 & Model 3 & Model 4 \\
\hline & Coefficient & Coefficient & Coefficient & Coefficient \\
\hline LnIN & $0.875^{\mathrm{a}}$ & $1.502^{\mathrm{b}}$ & $1.502^{\mathrm{b}}$ & $1.014^{\mathrm{a}}$ \\
\hline LnTK & 0.072 & 0.310 & 0.310 & 0.196 \\
\hline LnIN*LnIN & & -0.043 & -0.043 & \\
\hline LnIN*LnTK & & Excluded & & -0.010 \\
\hline LnTK*LnTK & & 0.031 & 0.031 & \\
\hline Constant & $1.565^{\mathrm{a}}$ & -0.641 & -0641 & -0.232 \\
\hline F stat & $2500.73^{a}$ & $1244.73^{\mathrm{a}}$ & $1244.73^{a}$ & $1681.79^{a}$ \\
\hline $\mathrm{R}^{2}$ & 0.994 & 0.994 & 0.994 & 0.994 \\
\hline $\operatorname{Adj} R^{2}$ & 0.994 & 0.994 & 0.994 & 0.994 \\
\hline
\end{tabular}




\begin{tabular}{lcccc}
\hline \multirow{2}{*}{ Variable } & \multicolumn{4}{c}{ Year 2017 } \\
\cline { 2 - 5 } & Model 1 & Model 2 & Model 3 & Model 4 \\
\cline { 2 - 5 } & Coefficient & Coefficient & Coefficient & Coefficient \\
\hline LnIN & $0.858^{\mathrm{a}}$ & $1,780^{\mathrm{a}}$ & $1,780^{\mathrm{a}}$ & $0,855^{\mathrm{a}}$ \\
\hline LnTK & 0.085 & $-0,915^{\mathrm{b}}$ & $-0,915^{\mathrm{b}}$ & 0,085 \\
\hline LnIN*LnIN & \multicolumn{5}{c}{} \\
\hline LnIN*LnTK & Excluded & \\
\hline LnTK*LnTK & & $-0,071^{\mathrm{b}}$ & $-0,071^{\mathrm{b}}$ & 0,00008561 \\
\hline Constant & $1.665^{\mathrm{a}}$ & $0,089^{\mathrm{b}}$ & $0,089^{\mathrm{b}}$ & \\
\hline F stat & $4781.71^{\mathrm{a}}$ & $2628.44^{\mathrm{a}}$ & $2628,44^{\mathrm{a}}$ & $3083,01^{\mathrm{a}}$ \\
\hline $\mathrm{R}^{2}$ & 0.997 & 0.997 & 0,997 & 0,997 \\
\hline Adj R & 0.997 & 0.997 & 0,997 & 0,997
\end{tabular}

Dependent Variable: LnQ

$\left({ }^{\mathrm{a}} \operatorname{sign} \alpha=0,01 ;{ }^{\mathrm{b}} \operatorname{sign} \alpha=0,05 ;\left({ }^{\mathrm{c}} \operatorname{sign} \alpha=0,10\right)\right.$

Source: BPS (Statistic Indonesia), 2018, Own Calculations

Different from 2017, Table 1 shows that the estimated Model 1 to Model 4 conforms with the theory that LnIN and LnTK variable coefficient is positive. However, of the four models, a model that can describe the overall translog production function is Model 3. The model shows that the value of the input positive and significant impact on the value of output, but the expenditure of labor is not a significant effect on output. Then the higher the value of labor expenditure for the effect on output increases. At the beginning of labor expenses rise continuously, but after surpassing a certain optimum point of this labor expenses down.

\section{Estimation of Translog Production Function of Small-scale Industry}

Table 2 presents the results of the production function translog estimates for 2015, 2016 and 2017. For 2015 and 2017, Table 2 shows that the estimation of Model 1 (linear translog function) is following the theory that the LnIN and LnTK variables are positive. In this estimation of Model 1, the output elasticity is constant. In Model 2 (second-order or complete quadratic linear translog function) the LnIN*LnTK variable is expressed as an excluded variable, so it is not included in the estimation, and the result is Model 3. However for 2015, the estimation of Model 3 is not under the theory, where the LnTK coefficient is negative, but for 2017 the LnTK coefficient is positive. While the estimation of Model 4 (linear translog function with interaction) is following the theory. Whereas for 2016, the estimation of Model 1 to Model 4 is following the theory where the coefficient of the LnIN and LnTK variables is positive. But of the four models, the model that can describe the overall translog production function is Model 3.

From Table 2, the production function translog most appropriate for small industries analyzed for 2015 and 2017 is model 4. The model suggests that the value of the input and labor expenditures and significant positive effect on the value of output. Changes in the value of the input and output interaction of labor can increase the value of output but not significantly. As for 2016, the most appropriate model for analysis is Model 3. The model shows that the value of the input positive and significant impact on the value of output, but the expenditure of labor is not a significant effect on output. Then the higher the value of labor expenditure for the effect on output increases.

\section{Output Elasticity of Micro Industries and Small-scale Industries}


According to Jaza (2014), assessment models translog function is less precise when only partially analyzed or tested. Therefore, Damanik \& Effendi (2009) stated that the analysis more applicable to translog production function is through the numbers elasticity.

\section{a. Micro Industries}

Based on estimates of a translog function chosen for the micro industrial business, the value of the elasticity of output is as follows:

Year 2015:

$\operatorname{Ln} Q=1.298+0.826 \operatorname{LnIN}^{a}+0.145 \operatorname{LnTK}+0.001(\operatorname{LnIN})(\operatorname{LnTK})+e$

(1) $\delta \operatorname{LnQ} / \delta \operatorname{LnIN}=0.826+0.001 \operatorname{LnTK}$

(2) $\delta \operatorname{Ln} Q / \delta \operatorname{LnTK}=0.145+0.001 \operatorname{LnIN}$

Table 2. Estimation of Translog Production Function of Small-scale Industry Year 2015-2017

\begin{tabular}{|c|c|c|c|c|}
\hline \multirow{3}{*}{ Variable } & \multicolumn{4}{|c|}{ Year 2015} \\
\hline & Model 1 & Model 2 & Model 3 & Model 4 \\
\hline & Coefficient & Coefficient & Coefficient & Coefficient \\
\hline LnIN & $0.792^{\mathrm{a}}$ & $1.349^{c}$ & $1.349^{c}$ & $0.895^{\mathrm{a}}$ \\
\hline LnTK & $0.199^{\mathrm{b}}$ & -0.226 & -0.226 & $0.321^{\mathrm{b}}$ \\
\hline LnIN*LnIN & & -0.041 & -0.041 & \\
\hline LnIN*LnTK & & Excluded & & -0.008 \\
\hline LnTK*LnTK & & 0.033 & 0.033 & \\
\hline Constant & $0.903^{\mathrm{a}}$ & -0.199 & -0.199 & -0.619 \\
\hline F stat & $1106.70^{\mathrm{a}}$ & $541.12^{\mathrm{a}}$ & $541.09^{\mathrm{a}}$ & $734.17^{\mathrm{a}}$ \\
\hline $\mathrm{R}^{2}$ & 0.987 & 0.987 & 0.987 & 0.987 \\
\hline $\operatorname{Adj} R^{2}$ & 0.986 & 0.985 & 0.985 & 0.986 \\
\hline
\end{tabular}

\begin{tabular}{lcccc}
\hline \multirow{2}{*}{ Variable } & \multicolumn{4}{c}{ Year 2016 } \\
\cline { 2 - 5 } & Model 1 & Model 2 & Model 3 & Model 4 \\
\cline { 2 - 5 } & Coefficient & Coefficient & Coefficient & Coefficient $^{\mathrm{a}}$ \\
\hline LnIN & $0.685^{\mathrm{a}}$ & $1.014^{\mathrm{a}}$ & $1.014^{\mathrm{a}}$ & $0.782^{\mathrm{a}}$ \\
\hline LnTK & $0.314^{\mathrm{a}}$ & 0.165 & 0.165 & $0.424^{\mathrm{a}}$ \\
\hline LnIN*LnIN & \multicolumn{5}{c}{-0.023} & -0.023 \\
\hline LnIN*LnTK & Excluded & \\
\hline LnTK*LnTK & & 0.011 & 0.011 & -0.253 \\
\hline Constant & $1.070^{\mathrm{a}}$ & -0.239 & -0.239 & $4604.10^{\mathrm{a}}$ \\
\hline F stat & $6198.29^{\mathrm{a}}$ & $3387.48^{\mathrm{a}}$ & $3387.48^{\mathrm{a}}$ & 0.998 \\
\hline $\mathrm{R}^{2}$ & 0.998 & 0.998 & 0.998 & 0.997 \\
\hline Adj R & 0.997 & 0.997 & 0.997 & \\
\hline
\end{tabular}

\begin{tabular}{|c|c|c|c|c|}
\hline \multirow{3}{*}{ Variable } & \multicolumn{4}{|c|}{ Year 2017} \\
\hline & Model 1 & Model 2 & Model 3 & Model 4 \\
\hline & Coefficient & Coefficient & Coefficient & Coefficient \\
\hline LnIN & $0.596^{\mathrm{a}}$ & 0.253 & 0.253 & $0.598^{\mathrm{a}}$ \\
\hline LnTK & $0.384^{\mathrm{a}}$ & $0,712^{\mathrm{a}}$ & $0.712^{\mathrm{a}}$ & $0,386^{\mathrm{a}}$ \\
\hline LnIN*LnIN & & $0.029^{c}$ & $0.029^{c}$ & -0.000178 \\
\hline LnIN*LnTK & & Excluded & & \\
\hline
\end{tabular}


IJBE (Integrated Journal of Business and Economics) e-ISSN: 2549-3280/p-ISSN: 2549-5933

\begin{tabular}{lcccc}
\hline LnTK*LnTK & & $-0.032^{\mathrm{c}}$ & $-0.032^{\mathrm{c}}$ & \\
\hline Constant & $1.439^{\mathrm{a}}$ & $1.778^{\mathrm{a}}$ & $1.778^{\mathrm{a}}$ & $1.410^{\mathrm{b}}$ \\
\hline F stat & $6765.18^{\mathrm{a}}$ & $3552.55^{\mathrm{a}}$ & $3552.55^{\mathrm{a}}$ & $4364.97^{\mathrm{a}}$ \\
\hline $\mathrm{R}^{2}$ & 0.998 & 0.998 & 0.998 & 0.998 \\
\hline Adj R & 0.998 & 0.998 & 0.998 & 0.998 \\
\hline
\end{tabular}

Dependent Variable : LnQ

$\left({ }^{\mathrm{a}} \operatorname{sign} \alpha=0,01 ;{ }^{\mathrm{b}} \operatorname{sign} \alpha=0,05 ;\left({ }^{\mathrm{c}} \operatorname{sign} \alpha=0,10\right)\right.$

Source: BPS (Statistic Indonesia), 2018, Own Calculations

Year 2016:

$L n Q=-0.641+1.502 \operatorname{LnIN}^{b}+0.310 \operatorname{LnTK}-0.043(\operatorname{LnIN})^{2}+0.031(\operatorname{LnTK})^{2}+e$

(1) $\delta \operatorname{Ln} Q / \delta \operatorname{LnIN}=1.502-0.086 \operatorname{Ln} I N$

(2) $\delta \operatorname{LnQ} / \delta \operatorname{LnTK}=0.310+0.062 \operatorname{LnTK}$

Year 2017

$\operatorname{Ln} Q=1.683+0.855 \operatorname{LnIN}^{a}+0.085 \operatorname{LnTK}+0.000086(\operatorname{LnIN})(\operatorname{LnTK})+e$

(1) $\delta \operatorname{Ln} Q / \delta \operatorname{LnIN}=0.855-0.000086 \operatorname{LnTK}$

(2) $\delta \operatorname{Ln} Q / \delta \operatorname{LnTK}=0.085+0.000086 \operatorname{LnIN}$

Note: $\left({ }^{a} \operatorname{sign} \alpha=0.01 ;{ }^{b} \operatorname{sign} \alpha=0.05 ;{ }^{c} \operatorname{sign} \alpha=0.10\right)$

In 2015 elasticity of function (1) indicates that the partial elasticity of output $(Q)$, the greater the increase in the value of the input $(I N)$, if the expenditure of labor $(T K)$ is constant. Elasticity function (2) also indicates that the partial elasticity of output $(Q)$, the greater the increase in labor expenses $(T K)$, if the value of the input $(I N)$ is constant. For 2016, the function elasticity (1) indicates that the partial elasticity of output $(Q)$ decreases with increasing value of input, while the function elasticity (2) show that the partial elasticity of output $(Q)$, the greater the increase in labor expenses (TK). For 2017 is almost the same as in 2015, elasticity function (1) indicates that the partial elasticity of output $(\mathrm{Q})$, the greater the increase in the value of the input $(I N)$ if the expenditure of labor $(T K)$ is constant.

Based on the above interpretation, the elasticity of output values above are presented in Table 3 below:

Table 3. Output Elasticity Value of Micro Industries for Year 2015-2017

\begin{tabular}{cccc}
\hline Elasticity Function & 2015 & 2016 & 2017 \\
\hline$\delta \operatorname{Ln} Q / \delta \operatorname{LnIN}$ & 0.826 & $1.502-0.086 \operatorname{LnIN}$ & 0.855 \\
\hline$\delta \operatorname{Ln} Q / \delta \operatorname{LnTK}$ & 0.145 & $0.310+0.062 \operatorname{LnTK}$ & 0.085 \\
\hline
\end{tabular}

Source: Own Calculations

The values of the elasticity of output show that for 2015 and 2017, partially, changes in production due to changes in the input value is more elastic than the result of changes in labor expenses. This shows that to increase the yield of micro industrial production should increase input values. But the elasticity analysis in 2016 obtained from the complete quadratic translog production function indicated that the production yield decreases with increasing input values, and yield increased with increasing labor expenses.

\section{b. Small-scale Industries}

Furthermore, for small-scale industries, the value of the elasticity of output is as follows:

Year 2015:

$\operatorname{Ln} Q=-0.619+0.895 \operatorname{LnIN}^{a}+0.321 \operatorname{LnTK}^{b}-0.008(\operatorname{LnIN})(\operatorname{LnTK})+e$

(1) $\delta \operatorname{Ln} Q / \delta \operatorname{LnIN}=0.895-0.008 \operatorname{LnTK}$ 
Year 2016:

$\operatorname{Ln} Q=-0.239+1.014 \operatorname{LnIN}^{b}+0.165 \operatorname{LnTK}-0.023(\operatorname{LnIN})^{2}+0.011(\operatorname{LnTK})^{2}+e$

(1) $\delta \operatorname{Ln} Q / \delta \operatorname{LnIN}=1.014-0.046 \operatorname{LnIN}$

(2) $\delta \operatorname{LnQ} / \delta \operatorname{LnTK}=0.165+0.022 \operatorname{LnTK}$

Year 2017:

$\operatorname{LnQ}=0.410+0.598 \operatorname{LnIN}^{a}+0.386 \operatorname{LnTK}^{a}-0.000179(\operatorname{LnIN})(\operatorname{LnTK})+e$

(1) $\delta \operatorname{LnQ} / \delta \operatorname{LnIN}=0.598-0.000178 \operatorname{LnTK}$

(2) $\delta \operatorname{LnQ} / \delta \operatorname{LnTK}=0.386+0.000178 \operatorname{LnIN}$

In 2015 elasticity function (1) indicates that the partial elasticity of output (Q), the greater the increase in the value of the input (IN), if the expenditure of labor (TK) is constant. Elasisitas function (2) also indicates that the partial elasticity of output (Q), the greater the increase in labor expenses (TK), if the value of the input (IN) is constant. For 2016, the function elasticity (1) indicates that the partial elasticity of output (Q) decreases with increasing value of INPUT, while the function elasticity (2) show that the partial elasticity of output $(\mathrm{Q})$, the greater the increase in labor expenses (TK). 2017 is almost the same as in 2013, elasticity function (1) indicates that the partial elasticity of output $(\mathrm{Q})$, the greater the increase in the value of the input (IN) if the expenditure of labor (TK) is constant.

Based on the above interpretation, the elasticity of output values above are presented in Table 4 following:

Table 4. Output Elasticity Value of Small-scale Industries For Year 2015-2017

\begin{tabular}{cccc}
\hline Elasticity function & $\mathbf{2 0 1 5}$ & $\mathbf{2 0 1 6}$ & $\mathbf{2 0 1 7}$ \\
\hline$\delta L n Q / \delta L n I N$ & 0.895 & $1.014-0.046 \operatorname{LnIN}$ & 0.598 \\
\hline$\delta L n Q / \delta \operatorname{Ln} T K$ & 0.321 & $0.165+0.022 \operatorname{LnTK}$ & 0.386
\end{tabular}

Source: Own Calculations

The values of the elasticity of output show that for 2015 and 2017, partially, changes in production due to changes in the input value is more elastic than the result of changes in labor expenses. This shows that to increase the yield of micro industrial production should increase input values. But the elasticity analysis in 2016 obtained from the complete quadratic translog production function indicated that the production yield decreases with increasing input values, and yield increased with increasing labor expenses.

\section{Level of Efficiency Value and Expenditure Labor Input}

Measuring the level of efficiency of input values and labor expenditures can be analyzed using the Cobb Douglas production function of short-term in the form of transformation (translog) or native form. Estimates of the level of efficiency are done by using a translog function model 1 in 2017, both for micro industries and small-scale industries. Based on Table 3 and Table 4 can be formed Cobb-Douglas production function of the short-term in the form of transformation as well as the original form for 2017, as presented in Table 5 below:

Table 5. Cobb-Douglas Production Function of Short Term

\begin{tabular}{ccc}
\hline \multirow{2}{*}{ Variable } & Micro Industries & Small-scale Industries \\
\cline { 2 - 3 } & Model 1 & Model 1 \\
\cline { 2 - 3 } & Coefficient & Coefficient \\
\hline
\end{tabular}




\begin{tabular}{ccc}
\hline LnIN & $0,858^{* * * *}$ & $0,596^{* * *}$ \\
\hline LnTK & 0,085 & $0,384^{* * *}$ \\
\hline LnIN*LnIN & & \\
\hline LnIN*LnTK & & $1,439^{* * *}$ \\
\hline LnTK*LnTK & $1,665^{* * * *}$ & $6765,18^{* * *}$ \\
\hline Constant & $4781,71^{* * * *}$ & 0,998 \\
\hline F stat & 0,997 & 0,998
\end{tabular}

Note: $\left({ }^{a} \operatorname{sign} \alpha=0.01 ;{ }^{b} \operatorname{sign} \alpha=0.05 ;{ }^{c} \operatorname{sign} \alpha=0.10\right)$

Source: Own Calculations

From Table 5, translog form is formulated as regression below:

Micro Industry $\quad: \operatorname{Ln} Q=1.665+0.858 \operatorname{LnIN}+0.085 \operatorname{LnTK}$

Small-scale Industry: $\operatorname{Ln} Q=1.439+0.596 \operatorname{LnIN}+0.384 \operatorname{LnTK}$

Then translog form is transformed to the form of natural logarithmic with basic value of e = 2.71828 (Gaspersz, 2011) and original form is formulated as below:

$\begin{array}{cc}\text { Micro Industry: } & Q=e^{0.665} I N^{0.858} T K^{0.085} \\ & Q=5.286 I N^{0.858} T K^{0.085} \\ \text { Small Industry: } & Q=e^{1.439} I N^{0.596} T K^{0.384} \\ & Q=4.216 I N^{0.596} T K^{0.384}\end{array}$

The constant coefficient of micro-industry and small-scale industry are shown in the original form of the Cobb-Douglas Production Function. The short-term efficiency index of the use of labor (TK) and input (IN) for micro industries is equal to the coefficient of intercept $=5.286$ while the efficiency index for small industries is about the coefficient of interception $=4.216$. This indicates that the level of efficiency in the use of input and output values of labor at the micro-industry is higher than the small-scale industry.

\section{Conclusion and Suggestion}

\section{Conclusion}

The profile of micro and small scale industries has expressed the business operational processes which include the presence of input, labor and output. Input implies the costs incurred in the production process. The labor is the number of workers/employees on average per day of work both paid and unpaid workers. While the output is the value of the output generated from the process of industrial activities expressed in terms of income. Therefore the three elements (input, labor, and output) have been estimated and analyzed to find out the relationship of the technical influence between inputs, labor and output in a production process. Translog production function model which is most suitable for production output to estimate micro and small-scale industries in Indonesia is a linear translog production function with interactions. In general, the value of the input and labor expenditure and significant positive effect on the value output micro and small-scale industries in Indonesia.

For micro industries, partial elasticity of output decreases with increasing value of input, and the partial elasticity of output, the greater the increase in labor expenses. For small-scale industries, partial elasticity of output increases with increasing value of input, and the partial elasticity of output decreases with increasing value of labor. For micro industries, increased spending on employment can increase output. This indicates that the micro industries put more 
emphasis on the allocation of a larger workforce. For small-scale industries, increasing the value of input can increase output. This suggests that the small scale industries more emphasis on the allocation of larger input values. Allocation of input values and labor expenditure is more efficient in micro industries compared with small-scale industries.

\section{Suggestion}

We recommend that in further studies, it is important to estimate the industrial output by using elements based on commodity inputs. To obtain the number of technical substitution and elasticity of substitution, the estimation can use technical data (not the data with value of money).

\section{References}

1) Agung, G.N., Pasay, N.H.A., Sugiharjo. (2008). Teori Ekonomi Mikro: Suatu Analisis Produksi Terapan. English Translation: Microeconomic Theory: An Analysis of Applied Production. Jakarta: Rajawali Press, PT.Rajagrafindo Persada.

2) Batool, S. A., \& Zulfiqar, S. (2013). Analyzing the Input-Output Relationship of Small and Medium Enterprises in Pakistan: An Econometric Approach. International Journal of Business and Economic Development, 1(1), 66-73.

3) Baum, C.F, \& Linz, T. (2009). Evaluating Concavity for Production and Cost Functions. The Stata Journal, 9(1), 161-165.

4) BPS (Statistic Indonesia). (2018). Survei Industri Mikro dan Kecil Tahunan 2017: Profil Industri Mikro dan Kecil 2017. English Translation: Indonesia Statistic Board: A Survey of Annual Micro and Small Industry 2017: The Profile of Micro and Small. Jakarta: Badan Pusat Statistik.

5) Dalton, P.S., Ruschenpohler, J., \& Zia, B. (2018). Determinants and Dynamics of Business Aspirations Evidence from Small-Scale Entrepreneurs in an Emerging Market. Policy Research Working Paper No. 8400 (pp. 1-44). New York: World Bank.

6) Damanik, S. \& Effensi, D.S. (2009). Analisis Fungsi Produksi Usahatani Kelapa dan Respon Petani Kelapa di Kabupaten Indragiri Hilir, English Translation: Analysis of Coconut Farming Production Function in District of Indragiri Hilir. Buletin Palma, 36(6), 62-75.

7) Evans, D., Green, C. J., \& Murinde, V. (2000). The Importance Of Human Capital And Financial Development In Economic Growth: New Evidence Using The Translog Production Function. Economic Research Paper. 00/17, pp. 1-33. Leicester, UK: Centre for International Financial and Economics Research Department of Economics, Loughborough University.

8) Farradinna, S., Fadhlia, T.N., \& Azmansyah. (2018). Entrepreneurial Personality in Predicting SelfRegulation on Small and Medium Business Entrepreneurs in Pekanbaru, Riau, Indonesia. Journal of Management and Marketing Review, 3(1), 34-39.

9) Fatusin, A. F. (2014). Characteristics of Industrial Labor among Small Scale Manufacturing Enterprises in Ondo State. Journal of Human Resources Management and Labor Studies, 2(2), 91111.

10) Gaspersz, V. (2011). Ekonomi Manajerial: Landasan Analisis dan Strategi Bisnis Untuk Manajemen Perusahaan dan Industri. English Translation: Managerial Economics: A Fundamental of Analysis and Business Strategy for Business Management and Industry. Jakarta: PT. Percetakan Penebar Swadaya.

11) Hamali, S. (2015). The Effect of Entrepreneurial Marketing on Business Performance: Small Garment Industry in Bandung City, Indonesia. Developing Country Studies, 5(1), 24-29.

12) Hamzah, M. Z., Dewi, K. A. S., Gunawan, I. D., \& Ratnaningtyas, H. (2018). Determinant Factors of the Distribution Growth at Micro, Small and Medium Business Credit in Indonesia Year of 20102015. OIDA International Journal of Sustainable Development, 11(7), 30-40. 
13) Hudcovský, M., Lábaj, M., \& Morvay, K. (2017). Employment Growth And Labor Elasticity In V4 Countries: Structural Decomposition Analysis. Prague Economic Papers, 26(4), 422-437.

14) Jasra, J. M., Khan, M. A., Hunjra, A. I., Rehman, R. A., Azam, R. I. (2011). Determinants Of Business Success Of Small And Medium Enterprises. International Journal of Business and Social Science, 2(20), 274-280.

15) Jaza, M. (2014). Analisis Pendapatan dan Efisiensi faktor-faktor Produksi Itik Pedaging di Kabupaten Bogor (Skripsi), English translation: Analysis of Income and Efficiency of Production factors of Duck Livestock in Bogor District. Bogor: Institute Pertanian Bogor (IPB).

16) Kageyama, M., Tokunaga, S., \& Akune, Y. (2006). An empirical analysis of agglomeration effect in the Japanese Food Industry: Panel analysis using flexible translog production function. The International Association of Agricultural Economists Conference, August 12-18 (pp. 1-25). Gold Coast, Australia: Gendai Advanced Studies Research Organisation Japan.

17) Khalil, A. M. (2005). A Cross-Section Estimate Of Translog Production Function: Jordanian Manufacturing Industry. Topics in Middle Eastern and African Economies, 7 (September 2005), 114.

18) Kim, H. Y. (1992). The Translog Production Function and Variable Returns to Scale. The Review of Economics and Statistics, 74(3), 546-552.

19) Kim, K. I. (2019). Investigation of Japanese electricity industry using a CGE model of translog function. Journal of Economic Structures, 8(1), 1-18.

20) Krishnapillai, S., \& Thompson, H. (2012). Cross Section Translog Production and Elasticity of Substitution in U.S. Manufacturing Industry. International Journal of Energy Economics and Policy, 2(2), 50-54.

21) Lin, B \& Atsagli, P. (2017). Inter-fuel substitution possibilities in South Africa: A translog production function approach. Energy, 121(C), 822-831.

22) Lyu, S. L., White, F.C., \& Lu, Y. (1984). Estimating Effects of Agricultural Research and Extensions Expenditure on Productivity: A Translog Production Function Approach. Southern Journal of Agricultural Economics, December 1984, 1-8.

23) Muwanga, G. S. (2017). Estimation Of Cob-Douglas And Translog Production Functions With Capital And Gender Disaggregated Labor Inputs In The USA. Journal of Smart Economic Growth, 2(3), 55-105.

24) Paridan, S. A. (2016). Pendugaan Elastisitas Permintaan Input Pada Usahatani Padi Sawah Di Kecamatan Tanah Sepenggal Kabupaten Bungo (Skripsi), English Translation: Estimation of Input Demand Elasticity on Rice Farmily. Jambi: Fakultas Pertanian, Universitas Jambi.

25) Pavelescu, F. M. (2011). Some aspects of the translog production function estimation. Revista Romana de Economie, 32(1), 131-150.

26) Pradan, K.C, \& Mukherjee, S. (2018). Examining Technical Efficiency in Indian Agricultural Production Using Production Frontier Model. South Asia Economic Journal, 19(1), 22-42.

27) Ray, S. (1999). Measuring Scale Efficiency from a Translog Production Function. Journal of Productivity Analysis, 11(2), 183-194.

28) Sahoo, B., Mohapatra, P., \& Trivedi, M. (1999). A Comparative Application of Data Envelopment Analysis and Frontier Translog Production Function for Estimating Returns to Scale and Efficiencies. International Journal of Systems Science, 30(4), 379-394.

29) Shanmugam, K.R \& Kulshreshtha, P. (2002). Efficiency of Thermal Power Plants in India. Vikalpa, 27(4), 57-68.

30) Soekartawi. (2003). Teori Ekonomi Produksi dengan Pokok Bahasan Analisis Cobb-Douglas, English Translation: Theory of Production Economic With Cobb-Douglass Analysis. Jakarta: PT. RajaGrafindo Persada.

31) Stern, D. (1994). Accuracy of the Ttranslog Function. Applied Economics Letters, 1(10), 172-174.

32) Widiastuti, R., Awang, S.A., Prayitno, T.A., Warsito, \& Sofyan, P. (2011). Kajian Stratejik Kelola Usaha Pada Industri Kecil Agel, English Translation: The Study of Business Strategic on Agel Small-scale Industry. Jurnal Riset Industri, 5(1), 1-11. 
IJBE (Integrated Journal of Business and Economics) e-ISSN: 2549-3280/p-ISSN: 2549-5933

33) Woo, T. H, \& Lee, U. (2011). Safeguard Assessment in Nuclear Power Plants (NPPs) Operations Using Analytic Hierarchy Process (AHP) and Production Function. Energy Exploration \& Exploitation Journal, 29(3), 337-356.

34) Yasar, M., Raciborski, M., \& Poi, B. (2008). Production function estimation in Stata using the Olley and Pakes method. The Stata Journal, 8(2), 221-231.

35) Yudawisatra, H. G. (2011). Analisis Pengaruh Modal dan Tenaga Kerja Terhadap Output Pada PT Telkomsel Regional IV, English Translation: Influence Analysis of Capital and Labor on Output: A Case Study of Telkomsel Regional IV. Jurnal ProMARK, 2(1), 41-52. 